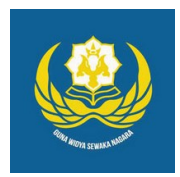

Jurnal Analogi Hukum

Journal Homepage: https://ejournal.warmadewa.ac.id/index.php/analogihukum

\title{
Pelaksanaan Perjanjian Kredit Pada Lembaga Perkreditan Desa (Lpd) Adat Mengwi
}

\author{
Ni Kadek Putri Candra Wati*, Ni Luh Made Mahendrawati dan Ni Made Puspa Sutari Ujianti \\ Universitas Warmadewa, Denpasar-Bali, Indonesia \\ *candrawati@gmail.com
}

How To Cite:

Wati, N, K, P, C., Mahendrawati, N, L, M., Ujianti, N, M, P, S. (2021). Pelaksanaan Perjanjian Kredit Pada Lembaga Perkreditan Desa (Lpd) Adat Mengwi. Jurnal Analogi Hukum. 3 (1). 32-36. Doi: https://doi.org/10.22225/ah.3.1.3026.32-36

\begin{abstract}
The aim of the presence of the Lembaga Perkreditan Desa Adat Mengwi is to improve the standard of living of the peoples at Mengwi vilage and to support the development of the Mengwi Vil, one of the program carried out by the LPD Mengwi is to distribute funds in the form of credit. In order that the LPD Desa Adat Mengwi not only distribute credit for the local people in Desa Adat Mengwi however it discord with the LPD Desa Adat Mengwi rules. The LPD Desa Adat Mengwi give some previllage to the debtor who is not from Desa Adat Mengwi. In this pasper there are two issues, namely: 1. How the implementation of the credit agreement at Mengwi Village and, 2. How the efforts made by the LPD Mengwi if the debtor is make defaults. This resesarch use the empirical method with the field research and sociological approach. At the implementation of credit agreements at the LPD Mengwi using a standard form of agreement which is contained in the from of an authentic deed and underhanded deed and in the implementation of the loan agreement procedure at the LPD Mengwi is similar to the general credit agreement procedure. The differences is only the terms of the agreement and the settlement efforts that carried out by the the LPD Mengwi as a creditor in case the debtor make default are with the first few stages by giving the first warning letter, if the debtor does not give any respond to the warning letter then there will be be the second warning letter, and if the debtor still does not give any respond there will be the third warning letter. And if there is dtill no respond from the debtor, The LPD Mengwi as a creditor will give a reprimand letter. If there is still does not any respond to the reprimand letter, the guarantee will be seized.
\end{abstract}

Keywords: Credit Agreement; Default; Lembaga Perkreditan Desa (LPD)

\begin{abstract}
Abstrak-Lembaga Perkreditan Desa Adat Mengwi hadir bertujuan untuk meningkatkan taraf kehidupan masyarakat desa adat mengwi dan menunjang pembangunan desa adat mengwi, salah satu kegiatan yang dilakukan oleh LPD adat mengwi adalah menyalurkan dana dalam bentuk kredit dalam memberikan pasilitas kredit LPD desa Adat Mengwi menyalurkan kredit tidak hanya kepada masyarakat didalam desa saja dimana dengan memberikan kredit kepada masyarakat diluar desa itu sendiri bertentangan dengan peraturan yang ada pada LPD Desa Adat Mengwi dan juga pada LPD Desa Adat mengwi memberikan pasilitas Kredit yang istimewa terhadap masyarakat di dalam desa tersebut. Dalam penelitian ini terdapat dua permasalahan yaitu: 1 . Bagaimana Pelaksanaan perjanjian kredit di LPD Desa Adat Mengwi dan, 2. Bagaimanakah Upaya yang dilakukan LPD Desa Adat Mengwi apabiala debitur wanprestasi. Metode yang digunakan adalah penelitian empiris dengan penelitian secara langsung kelapangan dengan teknik pengumpulan data dan melalui wawancara dan pendekatan sosiologis. Dalam prakteknya pelaksanaan perjanjian kredit di LPD Desa Adat Mengwi Menggunakan bentuk perjanjian baku dimana tertuang dalam bentuk akta otentik dan akta dibawah tangan dan dalam pelaksanaannya prosedure perjanjian kredit di LPD Desa Adat Mengwi sama saja dengan prosedur perjanjian kredit pada umumnya yang membedakan hanya syarat dalam perjanjian tersebut, dan upaya penyelesaian yang dilakukan oleh LPD Desa Adat Mengwi apabila Debitur Wanprestasi adalah dengan beberapa tahap pertama dengan memberikan surat peringatan I ,jika tidak direspon oleh debitur maka akan diberikan surat peringatan II, jika tidak merespon diberikan surat peringatan III, dan jika tidak direspon lagi maka akan diberikan surat teguran,apabila sampai ditahap pemberian surat teguran tidak direspon juga maka akan dilakukan sita jaminan.
\end{abstract}

Kata Kunci: Perjanjian Kredit; Wanprestasi; Lembaga Perkreditan Desa (LPD) 


\section{Pendahuluan}

Lembaga Perkreditan Desa seperti halnya bank, baik bank pemerintah maupun bank swasta yang ada di Indonesia adalah termasuk lembaga keuangan yang sangat penting peranannya di dalam pembangunan perekonomian di pedesaan (Yasa, Rudy, \& Kusuma, 2013).

Lembaga Perkreditan desa merupakan salah satu wadah kekayaan desa yang dimana fungsinya untuk meningkatkan taraf kehidupan masyarakat desa dan dan dalam menjalankan kegiatan banyak menunjang pembangunan desa

Kegiatan yang dilakukan LPD dalam menjalankan fungsinya yaitu menghimpun dana dan menyalurkan dana, dalam hal ini menghimpun dana bentuknya itu tabungan dan deposito, menyalurkan dana tersebut dalam bentuk kredit adalah penyediaan uang atau tagihan berdasarkan kesepakatan pinjaman antara keduabelah pihak. Semakin tinggi pertumbuhan kredit semakin tinggi pula kredit yang disalurkan, semakin tingginya pertumbuhan kredit maka pendapatan oprasional LPDpun semakin meningkatn, jadi dengan adanya kredit di LPD uang yang semula disimpan di LPD yang umumnya disebut sebagai uang beku/ idle money mengalami peningkatan setiap tahunya ini tentunya sangat menunjukkan bahwa kredit sangatlah berperannan penting dalam LPD dan sangat membantu masyarakat desa

Kredit sangat membantu masyarakat desa itu contohnya seperti jika ada masyarakat desa yang memiliki keinginan untuk membuka usaha baru tetapi tidak memiliki modal mereka dapat meminjam uang untuk modal awal dari usaha baru mereka di LPD. LPD dalam menyalurkan kredit tentunya memerlukan perlindungan hukum bentuk dari perlindungan hukum yang di terapkan oleh LPD untuk mendapatkan kepastian hukum adalah tertuang dalam bentuk perjanjian kredit perjanjian kredit yang digunakan adalah perjanjiang kredit yang tertuang dalam bentuk akta otentik dan akta dibawah tangan. Tentunya dalam perjalanan perjanjian kredit tidak selalu berjalan mulus diamana tidak dapat dipungkiri bahwa dalam pelaksanaannya pasti saja terdapat suatu permasalahan seperti debitur yang melakukan tindakan Wanprestasi. Dan di dalam memberikan pasilitas kredit LPD hanya dibolehkan untuk memberikan pinjman kepada masyarakat/ krama desa yang bersangkutan saja namun dalam prakteknya LPD di Desa Adat Mengwi dalam memberikan kredit tidak hanya kepada masyarakat desanya saja tentusaja hal ini akan mengakibatkan sulitnya dalam penyitaan jaminan jika terjadi tindakan wanprestasi dalam perjanjian kredit tersebut.

Dan di di LPD Desa Adat Mengwi tidak mempunyai perarem/ peraturan khusus yang mengatur tentang bagaimana jalannnya pelaksanaan perjanjian kredit di LPD tersebut dan LPD desa Adat Mengwi juga tidak memiliki perapem khusus yang mengatur tentang bagaimana jika terjadi tindakan wanprestasi pada LPD ini maka dari itu penulis ingin mengetahui bagaimana pelaksanaan perjanjian kredit pada LPD Desa Adat Mengwi dan Bagaimana Upaya yang dilakukan LPD Desa Adat mengwi apabila debitur di LPD tersebut melakukan tindakan wanprestasi mengingat LPD desa Adat Mengwi ini Tidak memiliki Perarem/ Peraturan yang mengatur hal tersebut. Jadi hal inilah yang melatar belakangi penulis unuk mengangkat judul "Pelaksanaan Perjanjian Kredit Pada Lembaga Perkreditan Desa (LPD) Adat Mengwi”.

Dari uraian latar belakang tersebut diatas maka penulis mendapatkan dua rumusan masalah yaitu: Bagaimana Pelaksanaan Perjanjian Kredit Pada LPD Desa Adat Mengwi, dan Bagaimana Upaya yang dilakukan LPD desa Adat mengwi apabila Debitur Wanprestasi.

Adapun tujuan prnrlitian ini yaitu untuk mengetahui bangaimana pelaksanaan perjanjian kredit pada LPD Desa Adat Mengwi dan mengetahui Upaya yang dilakukan LPD desa Adat Mengwi apabila Debitur Wanprestasi.

\section{Metode}

Untuk mengkaji permasalahan yang terjadi Pada LPD Desa Adat Mengwi penulis Menggunakan Metode penelitian dengan Tipe Penelitian Empiris dan Pendekatan Sosiologis dan sumber data yang digunakan adalah data primer yang dimana data-data yang diperoleh adalah dengan mengadakan penelitian secara langsung kelapangan, dan sumber data sekunder dimana datanya bersumber dari menelaah literatur-literatur yang berkaitan dengan permasalahan ini.

Penelitian ini berlokasi di LPD Desa Adat Mengwi Kecamatan Mengwi, Kabupaten badung. Dalam penelitian ini data yang didapatkan diolah secara kualitatif yaitu dengan menganalisis permasalahan yang timbul dan temui dalama pengamatan di lapangan.

\section{Hasil Penelitian dan Pembahasan}

Pelaksanaan Perjanjian Kredit Di Lembaga 
Perkreditan Desa (LPD) Adat Mengwi

Lembaga Perkreditan Desa Adat Mengwi beralamat di jalan Rama/ Pasar Mengwi Nomor 29, LPD Desa Adat Mengwi diresmikan pada tanggal 11 september 1986 bertempat di Desa Adat Samuan Kecamatan Petang Kabupaten Badung Berdasarkan Surat Keputusan Gubernur Kepala Daerah tingkat I Bali No 972/84 tanggal 01 November 1984 dan Surat Keputusan Kepala Daerah Tinggkat II Badung No. 580511/Bangdes Tanggal 11 september 1986. LPD Desa Adat Mengwi dalam proses berdirinya memiliki latar belakang yang berbeda dengan LPD lainnya yang ada di Bali, dimana LPD desa Adat mengwi merupakan Koperasi simpan pinjam di Desa Adat Mengwi. Modal usaha koperasi simpan pinjam Desa Adat Mengwi sebesar Rp. 6.574 .300 pada tanggal 11 september 1986 selanjutnya merupakan modal awal berdirinya LPD Desa Adat Mengwi. Ditambah dengan bantuan modal dari Pemda Tingkat I Bali sebesar Rp. 2.000.000 dan bantuan II dari Pemda Tingkat II Badung Berupa Mebuler dengan nilai sebesar Rp. 2.380.000 maka jumlah seluruh Modal awal LPD Desa Adat Mengwi pada Saat berdirinya pada tanggal 11 september 1986 semuanya berjumlah sebesar Rp. 10.954.300.

Dalam pemberian kredit untuk memperoleh kepastian hukum LPD desa adat mengwi mengikatkan dirinya dengan debitur dalam pentuk perjajian kredit, dimana perjanjian kredit tersebut harus memenuhi syarat sahnya suatu perjanjian yaitu pasal 1320 KUH Perdata:

Kesepakatan, kesepakatan berati kedua belah pihak sepakat untuk mengikatkan dirinya dalam suatu perjanjian kredit

Kecakapan, kecakapan adalah dkeduabelah pihak telah dianggap cakap untuk membuat suatu perjanjian kredit

Suatu hal tertentu, dalam perjanjian kredit harus diterang dengan jelas objek dari perjanjian kredit tersebut

Sebab yang halal, perjanjian kredit dibuat tidak boleh bertentangan dengan peraturan perundang-undangan yang ada (Miru, 2013).

Dalam hal mencegah suatu hal yang tidak dinginkan dikemudian hari LPDDesa Adat Mengwi memberikan kredit berdasarkan prinsip kehatihatian, dimana prinsip tersebut meliputi, prinsip 5 C's dan Prinsip 5 P ,3R. Dan langkah yang dilakukan oleh LPD Desa Adat Mengwi menurut wawancara pada tanggal 28 oktober 2018 dengan I Made Sudiarta, SH selaku bagian kredit di LPD Desa Adat Mengwi bentuk perjanjiankredit yang digunakan adalah bentuk perjanjian baku yang dimana tertuang dalam bentuk akta otentik dan akta dibawah tangan dan menurut beliau dalam memberikan kredit untuk krama/ masyarakat Desa Adat Mengwi tidak memerlukan akta pengikatan jaminan alasannya karena krama/ masyarakat Desa Adat Mengwi telah dikenal betul oleh pihak LPD dan pinjamannya tidak terlalu besar tetapi untuk pemberian kredit kepada krama/ masyarakat diluar Desa Adat Mengwi akan mengikatkan jamianannya dengan akta pengikatan jaminan.

Keterangan lebih rinci di jelaskan pada wawancara pada tanggal 28 oktober 2018 dengan I Made Mariana selaku Sekretaris/ Tata Usaha di LPD Desa Adat Mengwi, mengatakan bahwa pinjaman yang dilakukan oleh calon debitur dengan plafon Rp. 100.000 sampai dengan Rp. 500.000 tidak menggunakan jaminan khusus untuk krama/ masyarakat Desa Adat Mengwi. Namun apabila pemberian kredit lebih dari Rp. 500.00 kredit diberikan dengan menggunakan jaminan, benda bergerak dengan berupa BPKB (Buku Pemilik Kendaraan Bermotor) diikat dengan akta Fidusia. Jika pemberian kredit denga plafon mulai dari Rp. 50.000.000 sampai dengan Rp. 100.000.000 menggunakan jaminan benda tak bergerak berupa sertifikat tanah diikat dengan SKMHT ( Surat Kuasa Membebankan Hak Tanah) untuk plafon diatas Rp. 100.000.000 akan dipasang APHT ( Akta Pemberian Hak Tanggungan).

Berdasarkan hasil wawancara diatas tersebut, dapat diketahui bahwa dalam pelaksanaannya bentuk perjanjian yang digunakan oeleh LPD Desa adat Mengwi adalah bentuk perjanjian baku yang tertuang dalam akta otentik dan akta dibawah tangan dan mencerminkan bahwa prinsip kehati-hatian yang dikenal dengan istilah formula 5C's dan 7P khususnya terhadap unsur jaminan dan proteccion dalam pemberian perjanjian kredir pada LPD Desa Adat Mengwi sudah dilaksanakan dengan baik

Pemberian perjanjian kredit yang dilakukan oleh LPD Desa Adat Mengwi harus melalui prosedure tertentu. Pada dasarnya prosedur perjanjian kredit pada Bank umum dengan LPD sama saja yang membedakannya hanya syarat pengajuankreditnya saja, menurut wawancara dengan I Made Sudiarta, SH prosedure perjanjian kredit pada LPD Desa Adat Mengwi yaitu:

Tahap pengajuan permohonan kredit

Tahap pengecekan jaminan 
Tahap pengisian surat permohonan kredit

Tahap analisa pemberian kredit

Tahap pembuatan memorandum pengulasan kredit

Tahap penandatangan surat keputusan kredit (SKK) kredit

Tahap penandatanganan surat perjanjian

Tahap penandatanganan bukti pengeluaran kredit

Tahap penandatanganan surat kuasa menjual

Kewenangan LPD Desa Adat Mengwi dalam menyalurkan kredit hanya diperbolehkan menyalurkan kredit pada masyarakat/ Krama Desa mengwi saja namun dimana hal ini tertuang dalam pasal 7 (b) Peraturan Provinsi Bali Nomor 3 Tahun 2017 Tentang Lembaga Perkreditan Desa , namun dalam prakteknya di LPD ini menyalurkan dana kepada masyarakat/ Krama di luar Desa adat mengwi, menurut keterangan yang disampaikan oleh I Made Sudiarta,SH selaku bagian kredit di LPD Desa Adat Mengwi penyaluran kredit terhadap masyarakat diluar desa tersebut bertujuan untuk pengembangan LPD agar mencapai target yang telah ditentukan.

Dengan syarat khusus yaitu calon debitur dari luar desa tersebut harus memiliki penjamin yang berasa dari dalam Desa Adat Mengwi dan memiliki Los Pasar di Pasar Desa Adat Mengwi. Hal ini lah syarat yang membedakan prosedur perjanjian kredit di LPD dengan bank umum

Upaya yang Dilakukan oleh Lembaga Perkreditan Desa (LPD) Adat Mengwi Saat Debitur Wanprestasi

Dalam perjanjian kredit keduabelah pihak wajib untuk memenuhi suatu prestasi yang ada pada perjanjian tersebut, pertasi dalam perjanjian kredit adalah suatu hal yang bisa dituntut oleh pihak kreditur dan pihak debitur wajib untuk menunaikannya (Tobing, 2014). Namun seringkali dalam praktknya perjanjian kredit mengalami permasalahan, permasalahan yang timbul adalah dimana pihak debitur tidak menunaikan apa yang telah disepakati/ pihak kreditur tidak menunaikan prestasinya secara baik tindakan ini merupakan tindakan wanprestasi. Faktor-faktor terjadinya wanprestasi adalah: Calon Debitur

Faktor Dari Kreditur
Faktor dari luar dan kreditur (Ekstern)

Kenakalan debitur (Yahman, 2014)

Berdasarkan data tiga tahun terakhir yang penulis dapatkan di LPD Desa Adat Mengwi terdapat sekitar 5\% dari kredit yang disalurkan mengalami hambatan yaitu kurang lancarnya kredit yang dimana hal ini disebabkan oleh tindakan wanprestasi yang dilakukan oleh debitur, menurut wawancara pada tanggal 24 November 2018 dengan I Made Sudiarta, SH selaku bagian kredit di LPD Desa Adat Mengwi wanprestasi yang sering terjadi itu disebabkan oleh debitur sendiri dan bukan dari pihak LPD yang dimana debitur kebanyakan meminjm uang untuk membantu kelancaran usahanya namun usahanya mengalami kebangkrutan sehingga debitur tidak dapat membayar hutangnya dengan lancar. Debitur yang melakukan tidakan wanprestasi itu juga disebabkan oleh itikad debitur yang memang kurangbaik, dan wanprestasi juga disebabkan oleh keperluan dari debitur yang lebih mendesak dan debitur mengalami kecelakaan/ musibah sehingga dalam pembayaran kredit menjadi kurang lancar.

Upaya penyelesaian perkara wanprestasi terdapat 2 cara penyelesaian yaitu penyelesaian secara litigasi dan nonlitigasi, dan pada LPD Desa Adat Mengwi penyelesaian sengketa wanprestasi yang dilakukan oleh debitur yaitu dengan penyelesaian Nonlitigasi dimana menurut wawancara dengan I Made Sudiarta,SH pada tanggal 24 November 2018 selaku bagian kredit pada LPD Desa Adat Mengwi saat debitur wanprestasi upaya penyelesaian yang dilakukan oleh LPD Desa Adat Mengwi yaitu dengan melalui beberapa tahapan yaitu:

Lembaga perkreditan Desa LPD akan mengenakan bunga sebesar 5,00\% pada debitur yang melkukan tindakan wanprestasi dimana debitur tidak menepati isi perjanjian kredit yang mana debitur tidak boleh terlambat dalam membayar setiap bulannya, pernyataan ini tercantum dalam perjanjian kredit yang telah disepakati oleh keduabelah pihak

Dan apabila debitur tidak membayarnya juga selama 6 bulan berturut-turut maka pihak LPD akan memberikan Surat Peringan I (SP I), dan apabila selama 3 bulan pihak debitur tidak merespon juga maka pihak LPD akan memberikan Surat Peringatan II (SP II), dan apabila Surat Peringatan II tidak dihiraukan juga maka pihak LPD akan memberikan Surat Peringatan III (SP III) 
Apabiala Surat Peringatan III tidak direspon juga oleh pihak debitur yang melakukan tindakan wanprestasi maka pihak LPD akan Mengeluarkan Surat Teguran

Jika Surat Teguran tersebut sudah diberikan sebanyak 3 tiga kali berturut-turut pihak debitur tidak merespon juga maka pihak LPD akan melimpahkan permasalahan tersebut kepada Bendesa Adat.

Apabila bendesa Adat telah melakukan pendekatan terhadap debitur yang tidak melunasi kreditnya di LPD, namun tidak dihiraukan oleh pihak debitur, maka bendesa Adat akan melakukan paruman, dimana dalam paruman itu akan memutuskan sanksi apa yang akan diberikan oleh debitur yang melakukan tindakan wanprestasi tersebut.

Selanjutnya menurut wawancara dengan I Made Mariana pada tanggal 24 November 2018 selaku Tata Usaha di LPD Desa Adat mengwi tahap penyelesaian wanprestasi yang dalam tiga tahun terakhir ini adalah baru sampai di tahap pemberian surat teguran.

\section{Simpulan}

Dalam pelaksanaannya bentuk perjanjian kredit yang dignakan oleh LPD Desa Adat Mengwi adalah bentuk perjanjian baku yang dimana tertuang dalam bentuk akta otentik dan akta dibawah tangan dan prosedur perjanjian kredit yang di terapkan pada LPD Desa Adat mengwi sama saja dengan prosedure perjajian kredit pada umumnya yang membedakannya hanyalah syarat- syarat dari pemberian kredit dimana terdapat perbedaan dalam pemberian kredit terhadap Krama didalam Desa Adat Mengwi dengan krama yang berasal dari Luar Desa Adat Mengwi karena LPD tidak sebenrnya tidak diperbolehkan untuk menyalurkan kredit kepada masyarakat diluar Desa Adat Mengwi.

Dalam pelaksanaannya kredit yang diberikan terdapat debitur tidak selalu berjalan mulus yaitu terdapat debitur yang melakukan tindakan wanprestasi, upaya penyelesaian yang dilakukan olek LPD Desa Adat Mengwi saat debitur wanprestasi adalah dengan melalui penyelesaian secara nonlitigasi dimana melalui beberapa tahapan yaitu dengan mengenakan denda sebesar $5.00 \%$ jika tindakan wanprestasi yang dilakukan yaitu tidak membayar dengan tepat perbulannya, jiaka debitur tidak membayar nya juga selama 6 bulan maka pihak LPD akan akan memberikan Surat Peringatan I, jiaka Surat Peringatan I tidak dihiraukan maka pihak LPD akan Memberikan Surat Peringatan
III, dan jika sampai ditahap pemberian surat peringatan III tidak direspon maka pihak LPD akan memberikan Surat Teguran, jika sampai ditahap Surat Teguran diberikan selama 3 tiga kali pihak LPD akan melimpahkan permasalahan tersebut kepada Bendesa Adat dan Bendesa Adat akan melakukan pendekatan pada debitur yang melakukan tindakan wanprestasi tersebut jika pihak debitur tidak juga menghiraukannya maka Bendesa adat akan mengadakan paruman desa untuk menentukan sanksi yang akan di berikan untuk debitur yang melakukan tindakkan wanprestasi.

\section{DAFTAR PUSTAKA}
Miru, A. (2013). Hukum Perikatan Penjelasan Makna, cetakan kelima. Depok: PT Raja Grafindo Persada.

Tobing, D. (2014). Hukum Perjanjian Kredit. Seleman: laksBank Grafika.
Yahman. (2014). Karakteristik WANPRESTASI dan Tindak Pidana Penipuan. Jakarta: Prenada Media Grub.

Yasa, P. H., Rudy, D. G., \& Kusuma, A. A. G. A. D. (2013). Nasabah, Perlindungan Hukum Terhadap Dana Desa, Yang Disimpan Pada Lembaga Perkreditan (LPD). Kertha Semaya, 1(10). Retrieved from https://ojs.unud.ac.id/ index.php/kerthasemaya/article/ view/6848 